\title{
Precementitic Carbides in Tempered Martensite
}

\author{
by Earl C. Roberts
}

$T^{\mathrm{s}}$ HE third stage of tempering quenched steel is the development of cementite from an initial product which makes its appearance during the first stage. While studies of cementite have shown it to be relatively amenable to investigation, studies of the flrst stage product have been limited, for the most part, to evaluation of the physical changes it causes in the martensite in which it forms. Thus $\mathrm{X}-\mathrm{ray}^{1}$, magnetic, dilatometric, specific volume and hardness $^{2}$ determinations have all contributed to the evidence for its presence but because of its transitory nature the actual composition and structure of the carbon-bearing phase which precedes cementite formation have proved quite difflcult.

As a result of the physical determinations which were made on steel tempered to the first stage condition, the postulation has been that the changes which occur are typical of a transition phase or one which exists in a temporary or transient status. This picture has been somewhat altered, however, by the isolation of the carbide phases which occur in tempered steel. It now appears quite definite that the initial carbon-rich structure is not a transition precipitate, in the usual sense, but a distinct entity in itself with no coherency existing between the carbide and matrix. Its individuality also indicates that it forms in quenched martensite with greater rapidity than cementite, and its growth to larger particle size than early cementite ${ }^{3}$ must mean that the cementite particles form as a result of a competitive process. In such a process the initial carbide is visualized as gradually redissolving in the matrix and thus giving way to cementite precipitation.

Carbides showing a structure other than that of cementite were isolated previously in the hydrochloric acid cell used by Crafts and Lamont. Investigations made with a martensitic anode in a complex electrolytic cell have shown that it is possible to extract similar carbide structures in an apparently more perfect condition. Martensitic steel tempered to different states with respect to time and temperature has shown that a phase (or phases) other than cementite exists over a wider range of tempering conditions than was previously realized. More specifically, cementite is not the only carbide present after tempering a $1.06 \mathrm{C}$ Steel up to $16 \mathrm{hr}$ at $700^{\circ} \mathrm{F}\left(371^{\circ} \mathrm{C}\right)$ and up to $128 \mathrm{hr}$ at $500^{\circ} \mathrm{F}$ $\left(260^{\circ} \mathrm{C}\right)$.

The carbides obtained from each condition of the steel were identified by $\mathrm{X}$-ray diffractionreference being made to $X$-ray data obtained (a) from synthetically prepared carbides of the composition $\mathrm{Fe}_{20} \mathrm{C}_{4,}{ }^{5,6,7}$ and $\mathrm{Fe}_{.,} \mathrm{C}^{3,7}$ and (b) from cementite extracted from a plain carbon steel ${ }^{8}$. Even though special techntques were used in handling the extracted residues, the diffraction patterns were somewhat vague. Attempts to overcome this defect by compensating for fluorescence were fruitless. Chemical analyses have not been run because a special method has yet to be devised to prevent the dried residues from burning on exposure to air. Until analysis is possible, the only definite statement that can be made is that $\mathrm{Fe}_{20} \mathrm{C}_{9}$ (and possibly the $\mathrm{Fe}_{2} \mathrm{C}$ ), structures are present prior to the formation of cementite. It must be emphasized that, while the structure of the initial precipitate corresponds to that of $\mathrm{Fe}_{20} \mathrm{C}_{9}$ (or possibly $\mathrm{Fe}_{2} \mathrm{C}$ ), these formulas may not be indicative of the composition of the precipitate. Chemical analysis will be necessary before the composition of the various carbide residues is definitely known.

The fact remains, however, that the initial precipitate is not a transition form of cementite inasmuch as it maintains its identity even after removal of the supporting matrix by electrolytic isolation. Therefore, the initial carbide should be regarded, not as a stepping stone to cementite precipitation but rather as a distinct phase in its own right, having a greater rate of nucleation and growth than cementite.

\section{References}

${ }^{1}$ M. Arbusov and G. Kurdjumov: The Condition of Carbon in Tempered Steel, Journal of Physics USSR 5. (1941) 101.

2 D. P. Antia, S. G. Fletcher and M. Cohen: Structural Changes During the Tempering of High Carbon Steels, Trans. ASM 32 (1944) 290.

${ }_{3} \mathrm{~J}$. Trotter and D. McLean: Electron Microscope Studies of Quenched and Tempered Steel, Journal Iron \& Steel Inst., September 1949, 9.

${ }^{4}$ W. Crafts and J. L. Lamont: Secondary Hardening of Tempered Martensitic Alloy Steel, T.P. 2439, Metals Technology, September 1948.

${ }^{5}$ K. H. Jack: A Study of Interstitial Alloys of the Fe-C-N System, British Iron and Steel Research Assn., Project $\mathrm{MG} / \mathrm{C} / 26$.

${ }^{6}$ G. Hägg: Z. Physik, Chem. B8, 1930, 455.

${ }^{7}$ L. E. Hofer, E. M. Cohn and W. C. Peebles: Modification of the Carbide $\mathrm{Fe}_{2} \mathrm{C}$; Their Properties and Identification, Journal Amer. Chem. Soc. 71 (1949) 189.

${ }^{8} \mathrm{H}$. J. Goldschmidt: Interplanar Spacings of Carbides in Steels, Metallurgia, 40, No. 236, June 1949.

Earl C. Roberts is Research Assistant at Massachusetts Institute of Technology, Cambridge, Mass. 